\title{
Colombian Development-Induced Displacement - Considering the Impact of International Law on Domestic Policy
}

\author{
Beatriz Eugenia Sánchez* \\ René Urueña**
}

DOI: $10.21827 / 59 \mathrm{db} 6975 \mathrm{c} 4 \mathrm{ffd}$

\begin{abstract}
Keywords
COLOMBIAN INTERNAL DISPLACEMENT; DEVELOPMENT-INDUCED DISPLACEMENT; GUIDELINE PRINCIPLES ON INTERNAL DISPLACEMENT
\end{abstract}

\begin{abstract}
It is well known that Colombia is the country with the highest number of internally displaced people (IDP) in the world. Almost 7.5 million people have been forced to leave their homes for reasons related to the internal armed conflict, which lasted for over fifty years. In order to meet the level of assistance required and protect the population, the Colombian State has developed a complex public policy, structured around the Deng Principles. Now, along with the involuntary displacement caused by the armed conflict, which is well known and studied, there is also another process of displacement that has remained completely hidden and is linked to the implementation of the development model.

To this day the only forced displacement whose existence has been officially recognized in Colombia is that linked to the internal armed conflict. Exoduses caused by mining, the production of biofuels or any other kind of development project, face not only the absence of programmes to repair their rights and meet their basic needs, but also the denial of their status as IDPs. Indeed, authorities responsible for designing and implementing plans and projects on these industries have not recognized even the faintest possibility of them triggering an involuntary exodus.

What prevents Colombian policy makers from expanding the definition of IDP in order to include those displaced by development projects? Domestic factors, such as multinational companies' and Colombian government's interests in protecting an economic model based on the exploitation of natural resources, provide just part of the answer. It is needed to look into the interaction among the Colombian public policy on internal displacement and the global regimes of forced displacement and foreign investment to understand the complete picture.
\end{abstract}

\footnotetext{
Beatriz Eugenia Sánchez is researcher of the CIJUS- los Andes School of Law. She also teaches at IE University Law Faculty and at Universidad Pontificia de Comillas, both in Madrid. She has been a lecturer at Universidad Carlos III (Spain). She holds a doctoral degree (summa cum laude) in the Program of High Studies in Human Rights from the Universidad Carlos III.

** René Urueña is Associate Professor and Director of Research at the Universidad de los Andes School of Law (Colombia). He has been an Associate Professor at the University of Utah, a fellow at New York University and is a docent at the Institute for Global Law and Policy at Harvard Law School. He holds a doctoral degree (exima cum laude) in law from the University of Helsinki.
} 


\section{Introduction}

According to the UNHCR, Colombia had the world's largest number of internally displaced persons (IDPs) in 2016. More than 7.4 million people have been forced to leave their homes, ${ }^{1}$ most of them due to the internal armed conflict, which lasted for over fifty years. ${ }^{2}$ The sheer magnitude of this phenomenon, coupled with the fact that national authorities have developed a sophisticated policy based on the guidelines developed by the United Nations, has triggered scholarly interest both domestically and internationally.

Several approaches have been developed to explain and formulate possible solutions to this issue. Despite their diversity, all of them agree on the extreme complexity of this phenomenon, which interlinks rural conflict, the struggle of various armed actors, gross and systematic violations of human rights, a traditionally weak State apparatus with consequently limited control over vast areas of the country, a development model that favours large rural property and, last but not least, the illicit drug trade. The latter has permeated all instances of national life through corruption and has provided considerable resources to existing social conflicts, thus, triggering unusual brutality.

Despite the complexity of the situation, public policy designed to address its outcomes builds on the premise that the humanitarian challenge is solely the product of the armed conflict that took place in the country. Those who are violently expelled from their places of habitual residence as a consequence of any of the other factors described above cannot expect to receive the protection and assistance of the authorities. This is in sharp contrast with IDPs who have fled the armed conflict and who are entitled to a (admittedly limited) set of benefits. Moreover, those who have been forced to leave their homes due to the implementation of development projects related to mining or the production of biofuels face not only the absence of programmes to repair their rights and meet their basic needs, but also the denial of their status as IDPs. Indeed, authorities responsible for designing and implementing plans and projects regulating these industries have excluded even the faintest possibility of them triggering an involuntary exodus.

The position of the Colombian authorities is shocking, especially if one considers that, today, the link between development projects and forced displacement is widely accepted. In fact, most international institutions that promote such projects (for example the World Bank) have been busy designing courses of action to address population transfers and manage their proper resettlement.

What prevents Colombian policy makers from expanding the definition of IDP to include those displaced by development projects? To be sure, there is the sheer pressure of multinational corporations with interests in mining or bio-fuels, as well as the interests of the government in the exploitation of natural resources. Moreover, there are funding and budgetary issues, as the government seems reluctant to expand expensive IDP benefits to a whole new group of the population.

However, such explanations seem unsatisfactory. For one, not only the government, but also the courts have excluded this kind of forced migrants from the definition of IDPs. The bureaucratic/budgetary explanation, therefore, seems less likely,

1 UNHCR, Population statistics, at <http://popstats.unhcr.org/en/persons_of_concern> (accessed 3 August 2017).

2 After a complex process the Colombian government and the guerrilla group Fuerzas Armadas Revolucionarias de Colombia (FARC-EP), signed a peace agreement on 24 November 2016. This has been considered the start of the end of the internal armed conflict. But, it is important to highlight that the conflict is not over yet. There is still an important guerrilla group active: Ejército de Liberación Nacional (ELN). Also the criminal gangs, heirs of paramilitary groups are quite active in the country. 
as it was the judiciary who decided on these entitlements in the first place. Moreover, other policies that hinder unrestrained exploitation of such interests have in fact been adopted: for example, environmental concerns have frozen off-shore drilling in the Colombian Caribbean, social mobilization has blocked gold mining by the Canadian corporation Greystar, and Colombia has been a forerunner in the application of voluntary standards of security and human rights in extractive industries. Why is it then that the very notion of development-induced displacement is such an anathema in this country?

While we believe that there is much arm-twisting from powerful interests involved in this process, this paper suggests a different line of thinking. We argue that this approach is oblivious to the fact that most decisions connected with developmentinduced displacement are not taken on a merely domestic basis, but rather are the consequence of global interaction among agents in different States. In this sense, Colombia's refusal to include people displaced by development or economic projects within the category of IDPs can be better understood in reference to global regimes regulating IDPs, on one hand, and foreign investment, on the other. The first regime puts forward a broad definition of internally displaced population, which could arguably cover forced displacement induced by economic development projects. However, its provisions are mostly soft law and their enforcement depends on decisions taken at the national level. The second, by contrast, is backed by legally binding provisions, which are deeply distrustful of the national legal systems. In this sense, the investment regime bestows the international level with important decision-making powers, including the power to assess and decide on the adverse effects caused by foreign investments. Thus, while one of these legal regimes leaves the framing of the concept of displaced population to the national authorities, the other places severe constraints on its expansion, as the definition of IDPs would be an undue intervention of domestic authorities in matters that fall under the jurisdiction of international bodies.

The influence of these two regimes in Colombia, as discussed throughout this paper, can explain some of the voids in the country's IDP policy. This article explores, first, the context of forced exodus in Colombia. Then, the text analyses the solutions to the challenge of forced displacement, both at the international and national levels, and argues that this policy has focused solely on exodus caused by the armed conflict. This approach obscures the plight of those who have been expelled from their place of residence due to the implementation of development projects. This is despite the fact that, as discussed below, such population is increasing in the country as a result of the economic model adopted in recent years. Many of the companies associated with this type of exodus are multinationals, protected by the foreign investment regime. The investment regime, and its influence on the regulation of forced displacement, is studied in the sixth part of the text, which ends with brief conclusions.

\section{Internal Displacement in Colombia and Its Complexities}

Armed conflict has been identified as the main cause of internal displacement in Colombia. However, internal displacement in this country differs from the situation in other States, where a single, large-scale armed action has resulted in massive displacement. In Colombia, displacement often occurs on a lesser scale, as the head of the household is threatened or killed by armed actors in targeted actions. As a 
consequence, he or she (or their relatives) is forced to move. ${ }^{3}$ The result of this situation is that the displaced population has increased marginally year by year and, thus, the magnitude of the problem has only became apparent to society after years of silent exodus. Moreover, this led to the IDP originally being considered as homeless individuals in the main cities; that is, as a symptom of the general economic problem of urban poverty, and not as the specific by-product of a political armed conflict in the rural areas. While data is controversial, general awareness of the human tragedy suffered by a multitude of Colombians only became a matter of mainstream concern in the late 1990s. From then on, this phenomenon became evident and acquired a life of its own.

Although it remained unnoticed by the government and society for decades, forced displacement in Colombia can be considered a constant throughout the history of the country. Ultimately, it has been instrumental in the process of nation building, 'an engine of the country's history, a kind of vicious axis of destruction-reconstructiondestruction of economic, political, technical, ecological and cultural Colombian society' ${ }^{4}$. Its endurance is better explained not by the phenomenon itself but by its use as an instrument by different actors for various purposes. Displacement has been a weapon of war used by all parties to the conflict: an instrument that landowners have resorted to in order to expand their domains and a mechanism for the development of infrastructure projects such as dams, roads and hydropower plants. At the same time, it has become an indirect consequence of coca and poppy cultivation.

In essence, diverse actors used forced displacement as an instrument throughout the country's history to gain control over land, resources and human beings, either for strategic or purely economic purposes. That is, it has been a tool in various types of conflicts occurring since the beginning of the Republic, which remain unresolved to this day. To this instrumental exodus one should add displacements of another nature, which are not expected but accepted as possible consequences of actions taken in the internal armed conflict, of public policies to combat drug trafficking and of the implementation of plans for economic growth; particularly the extraction of raw materials and the development of infrastructure. ${ }^{5}$

Among the various instrumental uses of forced displacement, two have a particularly long historical tradition in the country: its use as a device of economic accumulation and expansion of large estates and as a combat strategy. These functions are directly related to two of the conflicts that have developed throughout Colombia's history, which have evolved as the country transformed itself to include new elements and dynamics, and still remain unsolved: conflict over land, and conflict for territorial control. $^{6}$

3 See Ibañez AM, El Desplazamiento Forzoso en Colombia: Un Camino Sin Retorno Hacia a Pobreza, (Bogotá, Ediciones Uniandes, 2008). It should be noted that as violence increased in the areas of Antioquia, Chocó and Cesar in 2001, cases of mass displacement became more common.

4 CODHES, Un país que huye. Desplazamiento y violencia en una nación fragmentada (Bogotá, Editora Guadalupe, 1999), 75.

5 Molano Bravo, A, "Desterrados" Papeles de Cuestiones Internacionales, Centro de Estudios para la Paz , No 70, Spring, 2000, p. 35, CODHES, Boletín informativo de la Consultoría para los Derechos Humanos y el Desplazamiento, $\mathrm{N}^{\mathrm{0}}$ 77, Bogotá, February 201, p. 3. Lemaitre, J (ed.) Derechos enterrados. Comunidades étnicas y campesinas en Colombia, nueve casos de estudio. (Bogotá, CIJUS-Uniandes, 2011), 15. Celis, R and Plaza, B, "Empresas trasnacionales y desplazamiento forzado. Una mirada crítica" Pueblos. Revista de información y debate (2016) at <http://www.revistapueblos.org/?p=20741> (accessed 15 September 2017).

6 CODHES, supra nt 4, 76. 
The first refers to one of the oldest social problems in the country: land distribution. The concentration of land ownership is extremely unbalanced in Colombia, where it is estimated that $1.4 \%$ of landowners own $65.4 \%$ of the surface area. ${ }^{7}$ There are several reasons for this over-concentration of land. The first is the implementation of an economic model that favours the production of raw materials for foreign trade which require large areas of land for certain crops, such as African palm, at the expense of peasant economies based on smallholding and polyculture. ${ }^{8}$ Secondly, Colombia has not implemented veritable rural reform. ${ }^{9}$ Furthermore, the State has not attempted to balance the situation of farmers. ${ }^{10}$ Thirdly, the rise of drug trafficking, particularly the 'laundering' of the financial assets involved, has influenced land concentration as traffickers have invested in the purchase of large areas and the exploitation of livestock, appropriating much of the most fertile areas. ${ }^{11}$

The second conflict, similarly unresolved, refers to the strategic territorial control of political and economic realms in the context of internal armed conflict. Armed actors attempt to capture governmental structures in certain areas of the country to control strategic corridors or assets. This is by no means a recent conflict, either. Its origins date back almost to the independence of Nueva Granada from the kingdom of Spain, in 1819. Since then the struggle between the various factions has become permanent. At this point, it is important to note that although the armed conflict has been a constant in the history of the country, one should avoid conceiving it as a single conflict, which manifests differently over time. Throughout the years, conflicts have been varied: both the actors and the idea of the struggle have changed in each phase. Experts refer to 'violences' in the plural, as a way of analysing the conflict, because each stage has brought different types of confrontations. ${ }^{12}$

The armed conflict currently unfolding has different characteristics from those in the two previous centuries. It is now a low-intensity struggle involving guerrilla groups, State armed forces, and criminal gangs. The latter are heirs of the paramilitary groups, which were formally demobilised in a process that took place between 2003 and $2006 .{ }^{13}$ Additionally, it features an extra ingredient that makes it even more complex: drug trafficking. Beginning in the sixties with the cultivation and trafficking of marijuana, this phenomenon has adapted very effectively to market requirements, as well as to the control strategies deployed against them by the State. The groups involved in this activity have allied themselves with the different actors in the conflict in order to protect their

7 Comisión de seguimiento a la política pública sobre desplazamiento forzado, VI Informe a la Corte Constitucional, (Bogotá, June 2008), 22, at <http://viva.org.co/documentos/cat_view/1-comision-deseguimiento> (accessed 9 August 2017).

8 Lemaitre, supra nt 5.

9 Failed efforts of rural reforms were undertaken in 1930, 1960 and 1980.

10 UNPD, Colombia rural. Razones para la esperanza. Informe nacional de desarrollo humano. (Bogotá, UNDP, 2011), $215 \mathrm{ff}$.

11 Reyes, A "Compra de tierras por narcotraficantes" in Thoumi, F (ed), Drogas ilicitas en Colombia: su impacto económico, politico y social, (Bogotá, Ariel-UNPD, 1994).

12 Sánchez, G and Peñaranda, R, (eds) Pasado y presente de la violencia en Colombia, (Bogotá, CEREC, 1995).

13 The demobilization process had the legal framework within Law 418 of 1997 (amended by Act 548 of 2002, 199 and 782). Also, Law 975 of 2005, known as the Justice and Peace law, regularly addressed the responsibilities of former combatants for acts committed 'during and at the time of membership' in the paramilitary groups, and the rights of their victims. For a critical view of the paramilitary demobilization process see Alonso, $\mathrm{M}$ and Valencia, G, "Balance del proceso de Desmovilización, Desarme y Reinserción (DDR) de los bloques Cacique Nutibara y Héroes de Granada en la ciudad de Medellín" 33 Estudios Politicos (2008). 
interests. So while certain regions have real armies to fight the guerrillas, others have come to an agreement with insurgent groups to pay for some type of revolutionary tax in exchange for the protection of their crops. On the other hand, though formally pursued by the State, which has received the support of the United States of America in developing an ambitious and aggressive programme in order to combat drug trafficking, ${ }^{14}$ corruption has allowed these groups to embed themselves at all levels of the State and society. ${ }^{15}$

In this new chapter of the Colombian armed conflict, forced displacement is sometimes the result of panic among the civilian population, caused by the fighting taking place near their villages and fields. However, this type of exodus, which might be called accidental, is secondary and occurs on a lesser scale than planned displacement, which has been used as a combat strategy by all sides. This has been done either for military purposes, for example, to control strategic corridors and areas of arms trafficking and other illegal products or for political goals such as the destruction of the social foundations of the adversary. ${ }^{16}$

These two conflicts (agrarian and armed) overlap and complement each other. In most areas it is a combination of the two factors which brings about displacement. For example, the Sierra Nevada de Santa Marta has become a battleground in which armed actors struggle for strategic control and various drug cartels fight for control of trafficking routes. At the same time, the Sierra has also become the backdrop of a dispute between indigenous communities and government officials over the implementation of several infrastructure projects. ${ }^{17}$

\section{IDP Policy as Global Governance}

Despite its particularities, the Colombian IDP crisis is part of a wider global picture. Though the phenomenon of individuals and populations fleeing their homes as a result of threats to their lives or physical integrity is almost as old as humanity itself, only in the twentieth century did the perception arise that there is a need for international protection and the development of a system that would manage the flow of communities and individuals fleeing from wars, internal conflicts or persecution. Several factors contributed to this transformation, which has brought this issue to the forefront of the attention of international institutions today. ${ }^{18}$

14 So far, two programs have been developed to combat drug trafficking with the strong support of the United States, which has provided material and financial resources for its development. This is the 'Plan Colombia', designed during the Clinton administration and 'Patriot Plan' promoted by the Bush administration, which is controversial given its poor results.

15 Reyes, supra nt 11; Garay, JL and Salcedo-Albarán, E Narcotráfico, corrupción y estados. Como las redes ilícitas han reconfigurado las instituciones en Colombia, Guatemala y México, (Bogotá, Debate, 2012).

16 According to the Third National Verification Survey, conducted by the National University in 2010, the main trail of displacements are direct threats. This was reported by $53.4 \%$ of households displaced recognized as such by the STATE. The second case, reported by $16.7 \%$, was the murder of a close relative. Such data supports the conclusion that the exodus is an end sought by the armed actors and not just collateral damage. See Comisión de Seguimiento a la Política Pública sobre Desplazamiento Forzado, Tercer informe de verificación sobre el cumplimiento de derechos de la población en situación de desplazamiento, (2010), 33-34, at <http://viva.org.co/cajavirtual/svc0236/articulo1175_236.pdf> (accessed 9 August 2017).

17 Lemaitre, supra nt 5.

18 Holborn, L. W. "The League of Nations and the Refugee Problem" Annals of the American Academy of Political and Social Science, Vol. 203, (1939), 124. Barnett L, "Global Governance and the Evolution of the International Refugee Regime” International Journal of Refugee Law Vol. 14, issues 2 and 3, (2012), $238-242$. 
The first step was taken after the First World War. The League of Nations had a High Commission for Refugees, created in 1921 under the direction of Fridtjof Nansen (who had before led the repatriation of prisoners of war from Siberia, acting as High Commissioner for the League of Nations). ${ }^{19}$ Seeking to address the problem of the exiled population fleeing the Bolshevik regime after 1917, Nansen proposed and implemented the so-called 'Nansen Passport', an identity document (yet not a passport, strictu sensu) issued by adherent States, that was valid for a year, and allowed the bearer to return to the country issuing it. ${ }^{20}$ The 'passport' was first issued to Russians, but subsequently extended to Republican Spaniards fleeing the Civil War, Armenians in 1924, and then to Kurds, Turks, Assyrians and Syrians in 1928, who had been expelled following the collapse of the Ottoman Empire. Later, German Jews fleeing the Third Reich were also given a 'passport'. ${ }^{21}$

The Nansen initiative was an early example of what would come to be the default approach to the problem of displaced populations in most of the twentieth century. In essence, the prevailing notion was that forced displacement became a problem as populations or individuals crossed borders; thus becoming, for example, 'refugees', or asylum seekers. Displacement was an intergovernmental problem, which concerned the relationship between States. ${ }^{22}$ This premise was confirmed by the effects of World War II, which resulted in the displacement of millions of people who sought refuge in a country different from their own. The Allies undertook to give these people some protection in 1944, through the United Nations Relief and Reconstruction Agency (UNRRA). UNRRA existed until 1947, when its mandate ended. In 1948, a temporary International Refugee Organization was set up as an agency of the United Nations (UN). Soon after, though, it became evident that the refugee problem was not of a temporary nature and a permanent UN High Commissioner for Refugees (UNHCR) was created in 1950.

Like its predecessors, and due to the demands of that particular period in history, the UNHCR was unconcerned with persons displaced within a country. In fact, the agency lacked a specific mandate to deal with such populations under its Statute. ${ }^{23}$ Article 9 of the Statute, however, did allow for the High Commissioner to 'engage in such additional activities, including repatriation and resettlement, as the General Assembly may determine, within the limits of the resources placed at his disposal'. As the tragedy of internally displaced people became evident, mainly outside Europe, the alternative offered by Article 9 proved useful. Thus, in the context of the Sudanese crisis of the early 1970's the UNGA 'urged the organizations associated with the United Nations and all Government to render the maximum possible assistance to the Government of Sudan in the relief, rehabilitation of Sudanese refugees coming from abroad and other displaced persons. ${ }^{24}$ Since then the UNHCR has seen its mandate with

19 Holborn, Ibid, 124.

Ibid, 680-684.

21 Barnett, supra nt 18, 238-242.

22 See Holborn, "The Legal Status of Political Refugees 1920 - 1939" Annals of the American Academy of Political and Social Science, Vol. 203, (1939) 387. For a useful historical review, see Barnett, supra nt 18, 239-245.

23 UN General Assembly, Statute of the Office of the United Nations High Commissioner for Refugees, 14 December 1950, (325th plenary meeting) A/RES/428/(V).

24 UN General Assembly, Assistance to Sudanese refugees returning from abroad, 12 December 1972, (2107th plenary meeting) A/RES/2958(XXVII), para 3 (emphasis added). 
regard to IDPs become broader and broader culminating in 1992 when the UNHCR was granted the competence to deal with this issue, which is now the default position. ${ }^{25}$

The expansion of UNHCR's mandate was not the only action taken by the United Nations to address forced migration within States. In 1992, the UN established the position of Special Representative of the Secretary-General on internally displaced persons. ${ }^{26}$ This unconventional mechanism, whose mandate was originally intended to last for a year, has survived until today but under the name of Special Rapporteur. His work has been essential in the creation of an international regulation of forced displacement. Indeed, in 1998 the then Representative, Francis M. Deng, submitted to the Human Rights Commission the Guiding Principles on Internal Displacement (hereinafter Guiding Principles), ${ }^{27}$ which are currently the backbone of this regime. These principles provide a comprehensive set of rights that must be guaranteed to persons in situations of internal forced exodus and proposes a model for care. National authorities are responsible for implementing this scheme and ensuring these rights. According to some commentators, if such duties are not met, the international community has standing to intervene to ensure the protection of IDPs. ${ }^{28}$ Others, in turn, see in this responsibility to protect an ill-defined notion that may justify neocolonial international interventions under the cloak of humanitarianism. ${ }^{29}$

Despite the involvement of the UNHCR, the organ of an international organization, IDPs are also (and perhaps predominantly so) a domestic problem: IDPs are protected by domestic laws and human rights instruments, as well as humanitarian treaties that apply at the national level. ${ }^{30}$ IDPs affect distribution of wealth, land ownership as well as gender and ethnic victimization; all within a single State. Ultimately, IDPs are first and foremost the responsibility of the State in which the displacement occurs. However, as we have seen, the UNHCR and other international institutions have much to do and say about the problem both, through regulating the problematic and providing aid to victims of displacement. Reaction to the IDP challenge is, therefore, a place where the agenda of an organ of a traditional intergovernmental organization (the UNHCR) and the agenda of national governments - their interests, and those of other national power structures - coincide. However, the two often clash as internal displacement becomes a delicate part of domestic politics or is even caused by the very government primarily responsible for the victims. It is a highly sensitive issue, as it affects not only the exercise of sovereignty, but also reveals the failure of domestic authorities in protecting their very own population and, in some cases, the State's interests in triggering displacement.

25 UN General Assembly, Office of the United Nations High Commissioner for Refugees, 20 December 1993 (85th plenary meeting) A/RES/48/116.

26 UN Economic and Social Council, Internally displaced persons, 20 July 1992, 1992/243.

27 UN Commission on Human Rights, Report of the Representative of the Secretary-General, Mr. Francis M. Deng, submitted pursuant to Commission resolution 1997/39. Addendum: Guiding Principles on Internal Displacement, 11 February 1998, E/CN.4/1998/53/Add.

28 The Guiding Principles are based on the theory of sovereignty as responsibility, according to which if a state fails to protect the human rights of its citizens, it is creating a void that the international community is required to fill. See Deng, FM, Kimaro, S, Lyons, T, Rothchild, D and Zartman, W, Sovereignty as Responsibility. Conflict Management in Africa, (Washington, Brookings Institution Press, 2010).

29 For a summary of the different views, see Focarelli, C, "The Responsibility to Protect Doctrine and Humanitarian Intervention: Too Many Ambiguities for a Working Doctrine" 13(2) Journal of Conflict and Security Law (2008) 191.

301948 Geneva Conventions and their Protocols provide some protection for IDPs, both during internal and international conflicts. 
The role of international law in IDP policy is a reflection of this circumstance. It has become common to argue that soft law plays an important role in the context of IDPs. ${ }^{31}$ This all-important role of soft instruments can be explained by the middle ground between international and domestic politics where IDPs stand. Consider the central normative piece to be found in IDP policy: the Guiding Principles, issued by the UN's Secretary-General's Special Representative on IDPs. The legal status of the Principles is rather ambivalent considering that it is neither a UN declaration nor is it an attempt at codifying customary international law. Rather, it is a study of domestic legislation and analogous regulation (for example refugee law), which is, in the words of the Representative of the UN Secretary General for Internal Displacement, 'consistent with international law' ${ }^{32}$

At the heart of these principles is the realization that several matters affecting IDPs are indeed covered by traditional (hard) international instruments: say, the right to life in human rights treaties, or the principle of distinction in international humanitarian law. This is the international aspect of the problem. However, there are other matters affecting IDPs that concern mainly domestic jurisdictions such as the compensation for property or land lost during the displacement or the possibility of finding a safe place within one's own State. Faced with such situations, norm entrepreneurs (for example activist and academic networks and the UN Representative of the Secretary-General for IDPs) quickly rose to support the drafting and adoption of some sort of normative framework that would address the limitations of the international aspect of the problem. ${ }^{33}$ The answer was the Guiding Principles. ${ }^{34}$ Although no hard international instrument was available, and any challenges fell to each State to address, some degree of governance could still be exercised through the Principles. IDP governance, then, is not strictly national or international but seems to include several layers of domestic governance complemented by the international actions of the UN and several networks of activists. This struck a certain balance: while the primary responsibility still fell on States, international involvement remained possible.

Francis M. Deng, Representative of the UN Secretary-General on IDPs, clearly portrays this dynamic in his description of his work at the UN:

In my dialogue with governments - one of the requirements of my mandate - the first five minutes with the head of state is [sic] crucial to assure them of my recognition of the problem as internal and therefore under state responsibility. Having emphasized my respect for their sovereignty, I quickly move on to present the positive interpretation of sovereignty and the supportive role of international cooperation. Once I establish a cordial climate, candid and constructive dialogue can follow with little or no constraint in the name of sovereignty. ${ }^{35}$

31 For a recent example, see Orchad, P, "Protection of internally displaced persons: soft law as a normgenerating mechanism" 36 Review of International Studies (2010) 281.

32 Kälin, W, Guiding Priciples on Internal Displacement. Annotations, The American Society of International Law, The Brookings Institution - University of Bern Project on Internal Displacement Studies in Transnational Legal Policy No. 38, (2008), 6.

33 Orchad, supra nt 31.

34 On the role of international norm entrepreneurs in the IDP context, see Cohen, R and Deng, FM, Masses in Flight: The Global Crisis of Internal Displacement (Washington, Brookings Institution Press, 1998), 283-285.

35 Deng, FM, "The Global Challenge of Internal Displacement" 5 Washington University Journal of Law and Policy (2001) 145. 
And then Deng concludes: 'the critical issue becomes how the international community can intercede to overcome the obstacles of negative sovereignty and ensure access for the needy population. ${ }^{36}$

The Guiding Principles are the basis on which the dialogue mentioned by Deng is developed. Even though the global IDP regime is a combination of hard and soft law, it merely presents a non-binding proposal to the State authorities. They are free to pick and choose which aspects to adopt as long as they respect the basic human rights deemed essential by the international community. This generates a special dynamic between global and local IDP government authorities. There is an ongoing dialogue in which the former tries to seduce the latter to adopt the entire proposal or, at least, its main elements. Analysis of this dialogue in different contexts such as the Colombian, Peruvian, Burundian or Turkish, reveals that at its core, protection for displaced populations has focused on armed conflict or generalized violence. In contrast, displacement caused by natural catastrophes or triggered by human action, ${ }^{37}$ as well as displacement caused by a certain model of development have been left behind. It could be argued, therefore, that failure to include such situations in domestic policies is the price that global institutions of government have been willing to pay to facilitate the acceptance of the rest of the (global) development deal.

\section{Colombian IDP Policy as a Species of Global Governance}

Although internal displacement in Colombia has a long history, ${ }^{38}$ it was only in the late 1990s that it became part of the public agenda as a specific problem that required a specialised response. Up to that moment, displacement was considered merely one effect, and not necessarily the most relevant one, of the 'real' threats: environmental disasters, terrorist activities and, especially, the internal armed conflict. This perception began to change in 1994 due to two factors. First, the conflict saw a surge of violence, which triggered an exponential growth of internal displacement. In 1995, the internally displaced population was close to half a million people, a fact that gave the issue visibility in domestic debates. ${ }^{39}$ Moreover, the UN Representative for IDPs visited Colombia in 1994 and, after meeting with officials and victims, published a report proposing the development of a policy specifically targeting the IDP crisis. ${ }^{40}$

As early as 1995, the administration recognized its deficiency in dealing with the IDP issue. ${ }^{41}$ In that year, the first system of aid for IDPs was developed under CONPES

36 Ibid.

37 The international community's interest in environmental displacement is quite recent and the Guiding Principles have played a secondary role in the search of solutions for this issue. See The Nansen Initiative, Agenda for the Protection of Cross-Border Displaced Persons in the Context of Disasters an Climate Change, (Geneva, The Nansen Initiative 2015), at <https://nanseninitiative.org/wpcontent/uploads/2015/02/PROTECTION-AGENDA-VOLUME-1.pdf> (accessed 9 August 2017).

38 Roldán, M, A Sangre y Fuego: La Violencia en Antioquia, Colombia, 1946-1953, (Bogotá, Instituto Colombiano de Antropología, 2003).

39 Conferencia Episcopal Colombiana, Derechos Humanos y desplazamiento interno en Colombia, (Bogotá, Kimpres, 1995) 33.

40 Commission on Human Rights, Internally displaced persons: Report of the Representative of the SecretaryGeneral, Mr. Francis Deng, submitted pursuant to Commission on Human Rights resolution 1993/95: Addendum: Profiles in displacement: Colombia, 3 October 1994, (51st Session) E/CN.4/1995/50/Add.1.

41 República de Colombia: Departamento Nacional de Planeacion, Programa Nacional de Atencion Integral a la Poblacion Desplazada por la Violencia, 13 September 1995, Conpes 2804; The Conpes (the National Council for Economic and Social Policy) is a legally established entity which serves as a consulting agency for the government in all of its aspects of economic and social policy. It produces several position papers named 'Conpes documents', which embody the decisions and recommendations taken by the national government regarding the areas of its jurisdiction. 
document 2805. While this first experiment failed to materialize in practice, it did set the basis for further policy and, most importantly, established the need for a straightforward policy to deal with the IDP crisis in Colombia. However, the document lacked a general view of the problem and seemed unaware of its magnitude. Two years later, Congress enacted Law 387 of 1997 (the 'Internal Displacement Attention Act'), which served as the legal framework for the integral aid that should be offered to IDPs and was the first legal recognition of their rights. ${ }^{42}$ The Act was drawn up with the collaboration of instances of global governance and arguably had some impact on the drafting of Deng's Guiding Principles on Internal Displacement which were adopted only a few months later in February 1998. ${ }^{43}$

Law 387 of 1997 laid the foundation for the creation of public policy dealing with IDPs. This public policy has been built on two pillars; both of them have been deeply influenced by the United Nations model dealing with this phenomenon, which is reflected in the Guiding Principles on Internal Displacement. ${ }^{44}$ The first one was established by the enactment of several Laws of Congress, beginning with Law 387 of 1997, which was then supplemented in 2008 by Law 1190 and Law 1448 of $2011 .{ }^{45}$ It was then developed by multiple executive decrees that established the institutional framework for the comprehensive care of people in forced exodus through prevention, humanitarian relief, economic stabilization and durable solutions. In spite of the amount of legislation, regulation and executive measures dealing with IDPs, the population was still not enjoying their rights, as they were still perceived as subjects of welfare (and private charity), not as rights holders. It was necessary, therefore, to adopt a human rights approach, which would ensure the full protection of IDPs. This was achieved through the extensive work of the Constitutional Court, which constitutes the second pillar of Colombian IDP public policy. The central piece of this column is the judgment T-025 of 2004, but there are many other relevant decisions. Through its judgments and writs the constitutional court has incorporate the rights contained in the Deng Principles into the domestic legislation in spite of their soft-law nature. In doing so the international proposal for managing IDPs has become the parameter to be utilized by domestic authorities in the context of national regulation. ${ }^{46}$

The combination of these two aspects has resulted in the most complex and ambitious Colombian social policy ever. ${ }^{47}$ This complex policy, however, only deals with

42 Law 387, Reglamentada Parcialmente por los Decretos Nacionales 951, 2562 y 2569 de 2001 por la cual se adoptan medidas para la prevención del desplazamiento forzado; la atención, protección, consolidación y esta estabilización socioeconómica de los desplazados internos por la violencia en la República de Colombia (24 July 1997).

43 This argument has been suggested before in Rodríguez, C and Rodríguez, D, "El contexto: E1 desplazamiento forzado y la intervención de la Corte Constitucional (1995-2009)" in Rodríguez C (ed.) Más allá del desplazamiento. Políticas, derechos y superación del desplazamiento forzado en Colombia (Bogotá, Ediciones Uniandes, 2010), 21.

44 Sánchez, BE, "Cuando los derechos son la jaula. Trasplante rígido del soft law para la gestión del desplazamiento forzado" 35 Estudios Politicos (2009).

45 Law 1448, Por la cual se dictan medidas de atención, asistencia y reparación integral a las víctimas del conflicto armado interno y se dictan otras disposiciones (10 June 2011); Law 1448 creates a mechanism that will facilitate the restitution of millions of hectares of lands abandoned or stolen as a result of human rights abuses and violations during the internal armed conflict. According to Article 60, Law $387 / 97$ complements its norms in IDPs issues. In decision C-280 of 2103, the Constitutional Court held that the obligations put forward by the prior norm were still in force.

46 Corte Constitucional, judgments SU-1150 of 2000; T-327 of 2001; T-098 of 2002; T-268 of 2003 and T025 of 2004.

47 Only the policy of reparation for victims of the armed conflict and land restitution, developed by Law 1448 of 2011 (supra nt 45) can be compared in terms of scope and ambition. 
internal displacement produced by the armed conflict. Even the Constitutional Court has ignored other kinds of forced migration. Development induced displacement is one of these.

\section{Development based on Extractive Industries and Forced Displacement in Colombia}

Development projects, beneficial as they may be in general, often trigger unwanted migration in communities whose lands are affected. This is well established, and numerous commentators have noted the disproportionate burden imposed on communities expelled from their place of habitual residence as a result. The issue is how to address this imbalance and restore the rights of the displaced. ${ }^{48}$ This has been taken up by international financial institutions, such as the World Bank ${ }^{49}$ and the Inter-American Bank for Development ${ }^{50}$ who have established policies to minimize exoduses and, where displacement is unavoidable, to minimize its negative effects by restoring the rights of those affected. However, the Colombian authorities have not adopted this course of action.

Even though forced migration resulting from the development of infrastructure and economic projects is not a new problem in Colombia, it has only been since the beginning of this century that this phenomenon has gone from having a marginal effect on specific projects, such as the construction of a hydropower dam, ${ }^{51}$ to becoming a systemic concern linked to the authorities' choice of an economic model for the country. Indeed, in the early 2000s, government officials chose to design and implement a development model based on extractive industries, with special emphasis on mining and power generation, so as to enter the international biofuels and feedstock markets. The adoption of this decision was possible because the country had already significantly adapted the rules and structure of economic production to suit the demands of the global economy. In the nineties, Colombia began a process of transforming the economy, through legal reforms and fiscal incentives to adopt neoliberal policies of structural adjustment imposed by international financial institutions. ${ }^{52}$ The economy was

48 Cernea, M, "Risks, Safeguards and Reconstruction: A Model for Population Displacement and Resettlement" in Cernea, M and McDowell, C, (eds) Risks and Reconstruction: Experiences of Resettlers and Refugees (Washington, The World Bank, 2000); Cernea, M and Kanbur, R, An Exchange on the Compensation Principle in Resettlement, Working Paper: Department of Applied Economics and Management Cornell University (October 2002); Robinson WC, "Risks and Rights: The Causes, Consequences, and Challenges of Development-Induced Displacement" Occasional Paper, The Brookings Institution-SAIS Project on Internal Displacement (2003); Rajagopal, B, (2000), Human Rights and Development, World Commission on Dams, Thematic Review V.4, Working Paper, at $<$ http://citeseerx.ist.psu.edu/viewdoc/download?doi=10.1.1.194.7417\&rep=rep1\&type=pdf $>$ (accessed 8 August 2017).

49 World Bank, Operational Manual O.P. 4.12 "Involuntary resettlement", April 2013, at <http://web.worldbank.org/WBSITE/EXTERNAL/PROJECTS/EXTPOLICIES/EXTOPMANUA L/0,,contentMDK:20064610 menuPK:64701637 pagePK:64709096 piPK:64709108 theSitePK:502 184,00.html> (accessed 1 June 2017).

50 Banco Interamericano de Desarrollo, Politica Operativa OP-710"Reasentameiteno involuntario", Octubre, 1998, at <http://idbdocs.iadb.org/wsdocs/getdocument.aspx?docnum=822554> (accessed 1 June 2017).

51 For example, during the nineties emberá and zenú communities were forced to leave their ancestral lands in order to build the hydroelectric project Urrá. Their case was studied by the Constitutional Court. See decision T-652 of 1998 . It is important to note that the court did not recognize this people as IDPs.

52 Sebastian, E and Steiner, R, La Revolución Incompleta: las reformas de Gaviria (Bogotá, Norma, 2008). 
deregulated, public utilities were privatized, the labour market was made more 'flexible', and property rights were strengthened. ${ }^{53}$

The adoption of the mining and agroindustry model of development in Colombia was complemented by a firm commitment to foreign investment. The government of President Álvaro Uribe Vélez (2002-2010) made 'investor confidence' one of its flagship programmes through linking the inflow of foreign capital into the country with the growth and development of the national economy. The government, thus, developed a series of measures to attract this type of investment, which have been maintained by the current administration of President Juan Manuel Santos (2010-2018). ${ }^{54}$ The development plan of the last government also notes that the growth of the energy and mining sectors, intended to become the engine for short-term development in the country, is subject to increased foreign capital inflows, which makes the development of new measures inevitable to facilitate their entry and stay in the country. As part of this openness to foreign investment, the country has embarked on a process of negotiating and signing free trade agreements in which foreign investment protection is a central concern.

The combination of these factors, that is, the Colombian bet on a development model based on extractive industries paired with the aggressive protection of foreign investments, has triggered the rapid growth of this sector with large areas of the country designated for such productive projects. Thus, between 2006 and 2016, the land area devoted to the growth of oil palm trees increased considerably to the point that by 2016 it was estimated that the crop occupied more than 466,000 hectares. ${ }^{55}$ As the total cultivated area of the country in 2014 amounted to 7.1 million hectares ${ }^{56}$, this means that slightly more than $6.5 \%$ of cultivated land is engaged in this agribusiness. More dramatic still has been the growth of mining, which is reflected in the mines licensing process. Between 2000 and 2010, the Ministry of Mining processed 17,479 requests and granted 7,264 mining titles throughout the country. This has affected 5.8 million hectares, which means that Colombia has almost as much land surface used or potentially being used for mining as for food production. ${ }^{57}$ It should be noted that currently this sector of the economy is the most attractive to direct foreign investment, to the point that most of the incoming investments have been made in this industry. ${ }^{58}$

Such an extensive growth of the biofuels industry and mining occurred in a country mired in armed conflict, facing complex problems of land distribution, and where State management of the rural areas has been characterized by privileging interests of large landholders. The government extensively supported projects that are not

53 Lemaitre, supra nt 5.

54 See generally: In the National Development Plan 2002-2006 'Towards a Communitarian State' the government set as one of its goals to develop a policy to attract such investment. The next plan, developed in Uribe's second term 'Community State: Development for All' restates this relationship, pledging to deepen and broaden this policy. The national plan for the period 2010-2014, 'Prosperity for All' prepared by the government of President Santos, remains on the same line, proposing actions and mechanisms to increase it, as well as the National Plan 2014-2018 'All for a New Country'.

55 FEDEPALMA, Federación Nacional de Cultivadores de Palma de Aceite Desempeño del sector palmero colombiano (2016), 8, at <http://web.fedepalma.org/sites/default/files/files/18072016_Desempen\%CC \%83o_sector_2015_2016.pdf $>$ (accessed 10 August 2017).

56 Departamento Nacional de Estadística (DANE) Censo Nacional Agropecuario (2014) at <https://www.dane.gov.co/index.php/estadisticas-por-tema/agropecuario/censo-nacionalagropecuario-2014\#entrega-de-resultados-del-3er-censo-nacional-agropecuario-preliminar $>$ (accessed 8 August 2017).

57 UNDP, supra nt 10, 97.

58 According to the 2010-2014 National Development Plan, almost $90 \%$ of foreign direct investment in 2009 targeted this sector. 
sustainable in environmental terms, without providing opportunities for most rural residents to participate in decision-making processes. ${ }^{59}$ In this context, it is not surprising that the development of these two economic sectors exacerbated existing tensions, deepened conflicts for land and territory, and led to the violent methods of dispossession and displacement.

It should be further noted that the areas where the resources for the development of extractive industries are located are, as a rule, located on the outskirts of the country. This is, in areas where the authorities have weaker control and where armed actors impose their law. Often, these areas also coincide with territories of indigenous and afroColombian people. These two ethnic communities have special fundamental rights to the lands they have traditionally occupied, as a result of the recognition of ethnic and cultural diversity in the Colombian Constitution. These rights are reflected in the recognition of collective property and the obligation of the authorities to consult with these communities when attempting to develop or exploit natural resources in their territory. ${ }^{60}$ Despite these special rights, such ethnic groups remain particularly vulnerable. Living in poverty, ${ }^{61}$ they are excluded from processes of development and are victims of constant violence. This is evidenced by the fact that Afro-descendants account for $10.6 \%$ of the population, yet constitute $22 \%$ of households displaced by force. Indigenous populations make up $3.4 \%$ of the Colombian population and account for $6.1 \%$ of the population living in involuntary displacement. ${ }^{62}$

The effect on these groups reflects the failure of the authorities to guarantee their rights and the violent pressures they are subjected to by various armed actors interested in gaining control of the land, both for its strategic position and for the wealth of the soil and subsoil. However, not only ethnic minorities are affected by displacement linked to the development model promoted by governmental bodies. Mestizo peasants living in these lands are also victims of dispossession and displacement.

Forced migration in this context occurs in three different ways. The first and most common, is when illegal armed groups force communities to sell their land cheaply, or simply to give it up. Once they gain control over the territory, title is acquired, allowing them to act as the legal owners and negotiate with the authorities and private investors the conditions for agricultural or extractive projects on these lands. The second is when mining and biofuel companies directly employ armed groups to expel the local population, thus, gaining control of the territories. Finally, the third way, affecting mainly indigenous people, is when environmental pollution and destruction of resources in their territories caused by the implementation of development projects forces people to leave their land. It is important to point out, though, that displacement is usually not directly caused by extractive industries, but rather by the illegal actors who strive to take over land and take advantage of an absent State.

Armed actors who undertake these tasks have often been identified as part of the paramilitary groups that participated in the armed conflict, as well as, more recently, the

59 UNDP, supra nt 10, 25-42.

60 Indigenous populations and afro-Colombians are beneficiaries of a mechanism of prior consultation, established as fundamental rights under Article 350 of the Colombian Constitution. The outcome of such consultation, though, is not binding - the state has the last word on the development of such projects; Sánchez, BE, "Estado multiétnico y entidad territorial indígena" in Estudios sobre descentralización territorial: El caso particular de Colombia (Cadiz, Universidad de Cádiz, 2006); Viana, A, El derecho a la consulta previa. Echando un pulso a la nación homogénea, (Bogotá, Pontifica Universidad Javeriana, 2016).

${ }^{61} 63 \%$ of the indigenous population is below the line of poverty, and $47.6 \%$ below the line of misery; UNDP, supra nt 10, 148.

62 Comisión de Seguimiento a la Política Pública sobre Desplazamiento Forzado, supra nt 16, 57. 
criminal gangs ('bandas criminales') that appeared after the demobilization of the paramilitaries. ${ }^{63}$ Moreover, the lack of a proper system of land registry in the country, coupled with the informality of land possession in most rural areas has undoubtedly contributed to this dynamic, facilitating the appropriation of land and the legalisation of its holding once transfers have been accomplished by forceful means. ${ }^{64}$

This type of forced migration has been completely ignored by the State, which refuses to acknowledge even the possibility that the economic model it enforces triggers this effect. There is neither an official record of the number of people affected by this phenomenon, nor statistics to provide an approximate figure. Nevertheless, displacement linked to the development of biofuel projects has been reported by international and national NGOs. ${ }^{65}$ It has also been analysed through multiple case studies. ${ }^{66}$ The situation faced by the black communities of Jiguamiando and Curvarado, in the department of Chocó, is probably one of the most studied. It is worthwhile to briefly outline the facts of this case as it illustrates the dynamics of this type of non-voluntary migration.

These communities consist of over a thousand families who live in an area where paramilitary presence has been common since the mid-nineties. While attacks on civilians were, from the beginning, a constant in the activity of these groups, they intensified after 1998 when several domestic and foreign companies initiated the development of a major project to produce biofuels from oil palm trees. As a result of these actions the two communities were forcibly evicted and their land used for the cultivation of this crop.

While these communities had been recognised as the owners of the land on which they lived, their titles failed to provide them protection. Rather, the titling process seems to have intensified the violence used to expel them. The response of the Colombian Ombudsman who reported the serious human rights violations faced by these people and urged the authorities to take action was ineffective, as it did not result in any actions designed to stop the violations and bring about reparation. ${ }^{67}$ The intervention of the InterAmerican human rights system through provisional protective measures ordered by the Inter-American Court proved ineffective in guaranteeing the right of these people to

63 Vidal, R, Salcedo, J and Medina, A Desplazamiento forzado y construcción de paz en Colombia 2009-2010 (Bogotá, CODHES - Pontificia Universidad Javeriana, Facultad de Ciencias Jurídicas - Embajada de Suiza, 2011); Rojas, G, "Post-demobilisation groups and forced displacement in Colombia: a quantitative approach" in Canor, D and Rodríguez, N, (Eds.), The new refugees. Crime and Forced Displacement in Latin America (London, Institute of Latin American Studies-London University, 2016).

64 UNDP, supra nt 10, 192; Comisión de Seguimiento a la Política Pública sobre Desplazamiento Forzado (2009) El reto ante la tragedia humanitaria del desplazamiento forzado: Reparar de manera integral el despojo de tierras y bienes, Bogotá, CODHES, 53 at <http://www.codhes.org/ codhes/images/Encuestas/ Vol\%205\%20Reparar\%20de\%20manera\%20integral\%20Tierras.pdf $>$ (accessed 9 August 2017).

65 UNDP, supra nt 10, 91; CODHES, Boletin informativo de la Consultoría para los Derechos Humanos y el Desplazamiento, Número 77 (15 February 2011).

66 See Celis and Plaza, supra nt 5 ; Valencia, J, et al, Cambio climático y desplazamiento ambiental forzado: Estudio de caso en la ecoregión Eje Cafetero en Colombia, (Armenia, Universidad La Gran ColombiaEditorial Universitaria, 2014), 114, 123-125; Correa, G and Hoyos, Y (Coords.) Impactos en los Derechos Humanos de la implementación del Tratado de Libre Comercio entre Colombia y Canadá. Linea base. Project Accompagnement Solidarité Colombie, June 2012, at <http://www.pasc.ca/es/article/impactos-enlos-derechos-humanos-de-la-implementacio\%CC\%81n-del-tratado-de-libre-comercio-entre> (accessed 15 September 2107).

67 Defensoría del Pueblo, Resolution 025/2002 (2002); Defensoría del Pueblo, Resolution 39/2005 (2005). 
return to their territories and restore land tenure. ${ }^{68}$ Today most of the members of these communities remain displaced and oil palms cover their properties. ${ }^{69}$

Although there are enough elements to establish a connection between paramilitary groups and at least one of the oil palm companies, these Afro-Colombian communities are officially considered displaced by the armed conflict. The authorities deny any relationship between the biofuel program and the forced exodus. In their minds, this is just another sad case of internal displacement caused by the war.

The development of mining has also created situations of involuntary displacement. Once again, authorities do not recognize the new engine of the economy as a trigger of this type of forced migration. However, in a 2011 report, Peace Brigades International notes that while only $35 \%$ of municipalities in the country have mining sites and energy resources, they represent $87 \%$ of the locations where forced exoduses have occurred, indicating a link official agencies are bent on denying. ${ }^{70} \mathrm{CODHES}$, in its report for the same year, also points to the relationship between displacement and mining and oil. ${ }^{71}$ Similarly, the shadow report on the implementation of the FTA between Colombia and Canada, ${ }^{72}$ provides evidence of the way in which mining projects funded by Canadian companies have contributed to the expulsion of local populations. ${ }^{73}$

Before concluding this section, one should note that this type of forced migration, generated by the implementation of a particular economic model, is strongly linked to traditional dynamics, in particular the struggle for land. This is, however, a different phenomenon since it involves foreign investment. This means these exoduses not only responds to the logic of the local or national economy but must also be analysed as part of the global deployment of a development model. Such a model has been adopted voluntarily by Colombia, or at least by its authorities, through public policy designed to benefit the public interest. Involuntary migration is, in this context, a price to be paid for the country's development. Thus, unlike the displacement generated by armed conflict or expansion of large estates, this type of involuntary migration could be managed in less harmful ways. This option, however, was never considered as official discourse insists on denying its existence.

68 The Inter American Court of Human Rights ordered provisional protection for this community on 6 March 2003. Since then, the Court has produced twelve more provisional measures. The last one was decided on 27 February 2012.

69 Lemaitre, supra nt 5, 47-66; Vidal, Salcedo and Medina, supra nt 63, 59-76; Radio Macondo, Curvaradó y Jiguamandó. Paramilitares continúan movilidad en predios colectivos, 17 January 2017, at $<$ http://radiomacondo.fm/2017/01/17/curvarado-jiguamiando-paramilitares-continuan-movilidadpredios-colectivos $>$ (accessed 30 April 2017).

70 Peace Brigades International, "Minería en Colombia: ¿A qué precio" 18 Boletín infomativo (2011), 6, at <http://www.peacebrigades.org/fileadmin/user_files/projects/colombia/files/colomPBIa/111122_bo letin_final_web.pdf $>$ (accessed 10 August 2017).

71 CODHES, Boletín informativo de la Consultoría para los Derechos Humanos y el Desplazamiento, Número 77 (15 February 2011), 3.

72 This treaty, which entered into force on 14 August 2011, establishes the obligation of the parties to submit an annual report to the national parliaments, on the effects of the treaty on human rights. In the absence of this report by the Colombian government, the group Solidarité Colombie Accompagnement Project has prepared its own report.

73 Correa and Hoyos supra nt 66. 


\section{Development-Induced Displacement: Coincidences and Divergences between the Global and Colombian Models}

It is possible to speak of a consensus on the relevance of development-induced displacement and on the dramatic consequences involved for people who are affected. There is no such consensus, however, on the global reaction to this situation. This stands in sharp contrast to the standards that are applicable to displacement induced by armed conflict.

The Guiding Principles are not conclusive as to the prohibition of moving populations in order to implement a particular economic model, to develop infrastructure or for development projects. It is assumed that these are carried out for the benefit of the whole population. The Principles merely establish standards of necessity and proportionality and prohibit discrimination. ${ }^{74}$ Thus, only people who are displaced due to projects that fail to meet these conditions can expect to benefit from the special protection of their rights as established by the international instrument.

This is a very limited recognition. Nevertheless, it can still be considered a victory as much controversy preceded this development. The travaux preparatoires of the Guiding Principles show an important debate as to whether development-induced displacement should be included.$^{75}$ While inclusion finally prevailed, the fact is that this population has received little attention from UN bodies responsible for IDPs under the Guiding Principles. The successive mandates of the UN special Representatives and Rapporteur for $\mathrm{IDPs}^{76}$ have focused their attention on the exodus caused by armed conflict and massive violations of human rights. Environment-induced displacement has gathered traction recently. ${ }^{77}$ Development-induced displacement, however, has been almost entirely ignored. ${ }^{78}$ In fact, global statistics of displacement fail to even register development-induced displacement. ${ }^{79}$

74 Walter, K, Guiding Principles on Internal Displacement: Annotations (Washington, The American Society of International Law, 2008) 32-33.

75 Mooney, E "The concept of internal displacement and the case for internally displaced persons as a category of concern" 24(3) Refugee Survey Quarterly (2005) 11.

76 Francis M. Deng was the first UN RSG for IDPs from 1992 to 2004 . He was succeeded by Walter Kälin, who remained in office until 2010. Currently, Chaloka Beyani is the Special Rapporteur on the human rights of internally displaced persons.

77 See supra nt 37. Kälin showed special interest for this kind of displacement. He created and promoted the Operational Guidelines on Human Rights in Situations of Natural Disasters; United Nations Human Rights Council, Report of the Representative of the Secretary-General on the human rights of internally displaced persons, Walter Kälin - Addendum Operational Guidelines on the Protection of Persons in Situation of Natural Disasters, UN Doc. A/HRC/16/43/Add.5, 31 Jan. 2011, 43. He also wrote several papers on this matter and promoted research about it. See Kälin, W, "Conceptualising Climate-Induced Displacement" in McAdam J. (dir.), Climate Change and Displacement. Multidisciplinary Perspectives, (Oxford, Hart Publishing, 2010).

78 In the 2010 report, Kälin mentioned that displaced by development-induced reasons should be protected under the same conditions as other displaced individuals; United Nations Human Rights Council, Report of the Representative of the Secretary-General on the human rights of internally displaced persons, Walter Kälin UN Doc. A/HRC/13/21, paras 45-46.

79 Since the beginning of the mandate of the Representative of the Secretary General for Internal Displacement, the need to create an information system on internal displacement was recognized. Given the lack of will and resources by the United Nations, the organization established a partnership with the NGO Norwegian Refugee Council and the Norwegian government, which allowed the creation in 1998 of the Internal Displacement Monitoring Centre (IDMC). Statistics published by this body reflect internal forced migrations generated by armed conflict and massive violence. Since 2009, it has included the report of the displacements generated by environmental disasters, has not made the same effort with those caused by the implementation of development projects; Internal Displacement Monitoring Centre, at $<\mathrm{http}: / / \mathrm{www}$.internal-displacement.org/>. 
The explanation for the lack of interest in this category of forced exodus can be found in the origins of the global regime. The regime was designed with a dual purpose: on the one hand, controlling forced population flows so that they do not become transnational and constitute a threat to international peace and security, and, second, to protect the rights of victims. Consequently, a policy and institutional framework has been developed, geared towards offering assistance and protection to refugees before crossing an international border, discouraging them from seeking attention beyond the national border. ${ }^{80}$ Displacement caused by the implementation of a specific economic model or by the implementation of development projects occurs often within the border of a given State, as the victims of this kind of exodus are not eligible for (international) refugee status. That is, if they leave their home State they will not be recognized as victims entitled to international protection but merely as irregular migrants. ${ }^{81}$ Therefore, this kind of mobility is not usually considered a threat to international peace and security and, hence, fails to trigger the attention of international institutions.

Nevertheless, limited as the international definition may be, the Colombian implementation of the global standard managed to limit it even further. Indeed, while the key elements of the international model have been adopted a more restrictive definition of IDP is used. Law 387 of 1997 includes in its definition of IDPs individuals who have been expelled from their homes as a result of armed conflict, generalized violence, and massive human rights violations. ${ }^{82}$ There is neither mention of development projects nor are environmental disasters recognised as the cause of an exodus. Years later, Law 1448 of 2011 made this definition even stricter, stating that IDPs are only persons who have left their place of usual residence due to events directly related to the internal armed conflict. $^{83}$

Despite constant criticism from civil society, the Constitutional Court endorsed this narrow definition of IDPs for a long time. ${ }^{84}$ In decision SU-1150 of 2000, the Court defines forced displacement as 'a social phenomenon that gives rise to multiple, massive and continuous fundamental rights violations of Colombians forced to migrate internally'. To be sure, these violations originate in the armed conflict affecting the country. The Court, thus, strictly interprets the causes of involuntary movements by the population set out in the first article of Law 387 of 1997, excluding displacement caused by conflict over land or by fumigations of illegal crops. ${ }^{85}$ Subsequent decisions confirm this interpretation, the clearest example being Decision T-025 of 2004, which cites the struggle for control by the State as the sole accepted cause of forced population movements in Colombia.

In 2013, the Constitutional Court departed somewhat from its earlier jurisprudence, acknowledging that two different situations in the country cause forced displacement: the armed conflict and clashes by criminal gangs. ${ }^{86}$ This decision has had a significant impact on the scope of the public policy designed for the protection of IDP

80 Sánchez, BE, supra nt 44; Peral, L, Éxodos masivos, supervivencia y mantenimiento de la paz, (Madrid, Trotta, 2001).

81 For more information on refugee status see: Goodwin-Gill, G, The Refugee in International Law, (Oxford, Clarendon Paperbacks, 1996).

82 Article 1, Law 387, (1997).

83 Article 3 and Article 60(2), Law 1448 (2011).

84 Vidal, R, Derecho global y desplazamiento interno. La creación, uso y desaparición del desplazamiento forzado por la violencia en Colombia (Bogotá, Pontificia Universidad Javeriana, 2007) 216-217.

85 Constitutional Court. Decision SU-1150 of 2000, para 42.

86 Constitutional Court. Writs 119 and 206 of 2013. These writs (autos) as well as all the judgments are available at Constitutional Court website: http://www.corteconstitucional.gov.co/relatoria/ 
rights. ${ }^{87}$ However, it did not take into account the impact of the economic model on the population expulsion. In fact, there is only one decision where this issue has been a subject of consideration.

Writ 005 of 2009, which addresses the special protection required for communities of African descent acknowledges that such populations may be subjected to displacement derived from 'the existence of mining and agricultural processes in certain regions that impose severe strains on their ancestral lands and facilitated their taking' ${ }^{88}$ This factor, combined with the structural marginalization to which these communities have been subjected, makes them particularly vulnerable to displacement by armed actors. This Writ could have opened the door for full recognition of a category of IDPs who were driven away from their homes as a result of economic development plans. However, it has had no impact on the design and implementation of IDP policy. So far, the main achievement has been the inclusion of the Afro-descendant communities in the protection and assistance programmes developed within the framework of Laws 387 of 1997 and 1448 of 2011. Beyond promoting such inclusion it has triggered few developments on the policy level. Moreover, as noted above, the norms dealing with the two core economic activities promoted by the Government fail to consider involuntary exodus as a possible cause. Consequently, they provide no regulation to prevent displacement, or to restore the rights of those affected.

Consider African palm cultivation. Aimed at producing biofuels, this crop has led to a sophisticated policy where the main instrument is the CONPES 3510 of 2008, 'Guidelines for policies to promote sustainable production of biofuels in Colombia'. Its key elements were developed in Law 939 of 2004 'Stimulus biofuel production'. The first document provides a detailed analysis of the advantages and disadvantages of introducing this crop on a large scale in the country. Clearly, this agribusiness development does not, per se, cause exoduses. However, in a context like the Colombian, the large-scale introduction of a crop that must occupy a wide area to be profitable can give rise to land dispossession. However, this effect was not anticipated. In fact, the CONPES document only refers to environmental risks such as loss of biodiversity, increased water pollution, and soil erosion, as well as a hike in food prices. ${ }^{89}$

Similarly, the basis for promoting the mining sector as the cornerstone of the Colombian development model is to be found in the National Development Plan for 2010-2014, which was approved by Law 1450 of 2011. This document highlights, once again, the environmental risks that the proposal entails and outlines steps to tackle such risks. It also identifies the need to establish channels of communication with the communities affected by the development of mining projects..$^{90}$ The displacement of the population living in the areas that are to be exploited is not considered a possible risk. The National Development Plan for 2014-2018, approved by Law 1753 of 2015, develops and deepens this economic model and, unsurprisingly, does not recognizes mining as a potential cause of forced displacement either. ${ }^{91}$

87 Due to the lack of a specific policy to address the IDPs produced by the activities of criminal gangs, the Constitutional Court ordered these people to be included in the existing protection framework.

88 Constitutional Court Writ 005 of 2009, para 67.

89 Departamento Nacional de Planeación (DNP), Programa Nacional de Atención Integral a la Población Desplazada por la Violencia, 13 September 1995, Conpes 2804, para 23-24 and 33.

90 Departamento Nacional de Planeación (DNP), Plan Nacional de Desarrollo 2010-2014. Prosperidad para todos, (Bogotá, DNP, 2010), Vol II, 231-232.

91 Departamento Nacional de Planeación (DNP), Plan Nacional de Desarrollo 2014-2018. Todos por un nuevo país, (Bogotá, DNP, 2014), Vol. I, 238-242. 


\section{Development-Induced Displacement and Foreign Investment Protection}

Foreign investment, as noted above, plays a crucial role in the adoption of the Colombian economic model, which is based on extractive industries. This source of income is essential for the development of oil and mining projects and, to a lesser extent, to agribusiness. It is not surprising that the government's efforts to facilitate initial and continuous investments have been pushed forward through the negotiation of numerous agreements on the protection of foreign investment, both as independent instruments, or integrated into FTAs. ${ }^{92}$

Given the undeniable link between foreign capital and a development model that, as we have seen, may generate displacement, this section explores the role played by foreign investment law in the evolution of the definition of IDP in Colombian policy. In order to address this, it is necessary to delve into the global regime dealing with the issue and its interaction with domestic law. Thus, we turn now to International Investment Agreements (IIAs), the centrepiece of this regime.

International Investment Agreements may be the single most important factor in transforming the global economic landscape today. A tight network of approximately 3300 IIAs covers the planet, ${ }^{93}$ crucially influencing decisions that may potentially impact sustainable development. However, despite their immense importance, governments, and the general public, appear not to grasp their specific scope and associated risks. One reason for this is the decentralized nature of the current IIA wave. Unlike similar agreements put together by institutions such as the WTO or the World Bank, investment deals are generally drawn up on a bilateral basis: ${ }^{94}$ there is no single decision-making centre that must be adhered to. Moreover, a considerable part of international investment regulation is developed through arbitration awards. Consequently, important legal principles have to be inferred from a patchwork of awards that are, in any case, guarded by a veil of secrecy.

Given their significance, it is important to explore these agreements in some detail. As hinted by their name, an IIA is an agreement between two or more States which sets out rules governing investments made by their respective nationals in the other state's territory. IIAs are not overseen by a single treaty organ, and come in different forms and shapes. The most common type is the Bilateral Investment Treaty (BIT), a self-standing instrument dealing mainly with investment. Furthermore, IIAs are also included as 'investment chapters' in free trade agreements - NAFTA's Chapter 11 being the most well-known example.

Substantively, the standard IIA provides investors with protection, among others, in four areas: market access, non-discriminatory treatment, a ban on expropriation and dispute settlement. The first three provide investors with fair conditions for participating in the new market. The last one ensures compliance through exceptional mechanisms of adjudication. Investment agreements usually grant arbitration tribunals jurisdiction over disputes between private investors and the Host State, providing private parties the right to stand before such international tribunals. ${ }^{95}$

92 Currently Colombia is part of free trade agreements with Mexico, Chile, MERCOSUR, Salvador, Guatemala, Honduras, the United States and Canada. It has also signed two FTAs with the European Union and South Korea, and has been involved in negotiations with Turkey, Panama, Costa Rica, Japan and Israel.

93 UNCTAD, World Investment Report, 2017: Investment and the Digital Economy (UN Publishing, 2017), 111.

94 The vast majority of all IIA's are bilateral investment treaties (BITs), Ibid.

95 Schreuer, C, "Calvo's Children: The Return of Local Remedies in Investment Arbitration" 4(1) The Law and Practice of International Courts and Tribunals (2005) 1; UNCTAD, Taking of Property: UNCTAD 
The combination of these four pillars makes investment arbitration a controversial element of global governance. ${ }^{96}$ Through IIAs, investment arbitration tribunals have jurisdiction to decide on projects of great importance to local communities, normally deciding between a government and a private actor in the midst of starkly opposed interests. One specific technique of convergence has emerged in the form of investment arbitration awards. Arbitration tribunals interpret the open-ended clauses included in the agreements, and their interpretation is then followed by other tribunals as the applicable law. These decisions are considered by arbitrators as hierarchically superior to any domestic law. As a consequence, foreign investment law can be read as a global constitution. For instance, David Schneiderman, in 'Constitutionalizing Economic Globalization', argues that investment arbitration is constitutional as it limits State power, yet it does so by carving out norms that give special protection to investors over citizens. Moreover, the regime 'freezes existing distributions of wealth and privileges the 'status quo neutrality" 97 ; enshrines neoliberal principles of governmental self-restraint as law; and is fundamentally 'out of balance' in democratic terms. ${ }^{98}$

Now, the basic premise of investment law is its distrust of the domestic legal systems of States that accept foreign direct investment. Investment arbitration features an underlying narrative that portrays domestic law as failing (or about to fail), and therefore in need of correction or reinforcement by the international investment tribunal. This corrective process is not formal: it is well known that investment tribunals have no formal power to strike down domestic law. However, the underlying notion is that investors need to be protected from arbitrary treatment by the host State and that domestic law is not up to that task. Hence, there is a need for international standards of protection, adjudicated by international judges instead of the domestic judiciary. The very existence of the investment regime is built upon the presumption that domestic law fails to adequately protect foreign investors.

This idea that domestic law fails to protect foreign investors is a powerful aspect of investment law. If we generalize the specific failures of the domestic law of host States and create the presumption that it is a failed system, the need for investment arbitration becomes logical and is deemed necessary to right the wrongs of domestic legal systems. Thus, the failed law premise is ideologically self-prophesying, as it results in the preservation of the distribution of powers between host States and investment tribunals. ${ }^{99}$ Ultimately, the presumption of failure of domestic law is hardly rebutted, and almost becomes a prejudice.

This issue is intimately connected to development-induced displacement. Displacement can be read, simultaneously, as a problem of IDP policy or as a negative externality of the investment law regime. This is a classical International Law fragmentation problem whereby the structural bias of each specialized system is

series on Issues in International Investment Agreements, 2000, UNCTAD/ITE/IIT/15, 12; Vasciannie, S, "The Fair and Equitable Treatment Standard in International Investment Law and Practice" 70(1) British Yearbook of International Law (2000) 99.

96 Van Harte, G and Loughlin, M, "Investment Arbitration as a Species of Global Administrative Law" (2006) 17 European Journal of International Law (2006) 121; Kingsbury, B and Schill, S, "Investor-State Arbitration, Fair and Equitable Treatment, Proportionality, and the Emerging Administrative Law of Global Governance" 9(46) NYU School of Law, Public Law Research Paper (2008).

97 Schneiderman, D, Constitutionalizing Economic Globalization: Investment Rules and Democracy's Promise, (Cambridge University Press, 2008), 37.

98 Ibid, 2, 9, 180 and 191.

99 Esquirol, J, "The Failed Law of Latin America" 56 American Journal of Comparative Law (2008) 75. 
deployed. ${ }^{100}$ Development-induced displacement is both an IDP and an investment law issue. Each provide somewhat different answers that complement each other. The IDP regime places the issue of IDPs squarely on the domestic level. Lacking legitimacy to intervene, global governance institutions rely on the domestic interpretation and implementation of global standards such as the Guiding Principles. In doing so, they rely on domestic politics to do the heavy lifting with regards to the question whether development-induced displacement should be considered as part of the global IDP agenda. As we have seen, this is not the case in Colombia. Instead, domestic IDP policy has closely followed global IDP principles but has specifically rejected the possibility of including development-induced displacement in its policy.

This decision becomes intertwined with the global investment regime. From the perspective of this regime, displacement could arguably be read as a potential risk that ought to be considered; as much as any other human rights which have found their way into the investment regime rationale. For example, environmental standards, the right to water, labour rights, all of which have in one way or another been considered (however marginally) by investment arbitration tribunals and instruments. ${ }^{101}$ Why should development-induced displacement not be considered? Perhaps the answer lies in the failed law premise discussed above. The investment regime presumes that domestic laws are fundamentally unreliable. Decision-making remains on the international level with other human rights, which is controversial but still reliable. However, the IDP regime places the responsibility of considering development-induced displacement on domestic authorities. In this sense, whatever decision is made in the domestic setting will be subject to suspicion from the foreign investment regime, as it is derived from a failed legal system.

The consequence of this move is not that the neo-liberal ideology of the investment regime prevents development-induced displacement from being considered. Nor is it that foreign investors, the protected subjects of the investment regime, press for a regime that excludes the legal protection of development-induced displacement. If asked, most would probably accept some level of protection. The point is that the structure of the international investment regime has no way of registering the issue of development induced displacement, which is left by default to domestic decision-makers.

The issue then becomes a never-ending circle of delegating responsibilities from the domestic to the global level and then back. Domestic IDP policy in Colombia has traditionally relied on global standards to justify its approach (hence, the Court's reliance on the Guiding Principles). But reliance on global governance implies that the decisions are made at the domestic level, which is in turn dependent on global policy, which further places decision-making on the domestic level. Faced with this, the investment regime cannot but shrug and classify development-induced displacement as a non-issue.

The end result is that the uncomfortable question of forced migration caused by an economic model based on extractive industries in which foreign investment is central is ignored both nationally and internationally.

${ }^{100}$ Urueña, R, No Citizens Here: Global Subjects and Participation in International Law (Leiden and Boston, Martinus Nijhoff Publishers, 2012).

101 Wheeler, D, "Racing to the Bottom? Foreign Investment and Air Pollution in Developing Countries" 10(3) The Journal of Environment \& Development (2001) 225-245; Bernasconi-Osterwalder, N and Brown Weiss, E, "International Investment Rules and Water: Learning from the NAFTA Experience" in Boisson de Chazournes, L, Bernasconi-Osterwalder, N and Brown Weiss, N, eds, Fresh Water and International Economic Law (Oxford, Oxford University Press, 2005); Sornarajah, M, The International Law on Foreign Investment, (Cambridge, Cambridge University Press, 2010); Waibel, M, The Backlash Against Investment Arbitration: Perceptions and Reality (Alphen Aan Den Rijn, Kluwer Law International, 2010). 


\section{Conclusion}

The absence of development-induced displacement in Colombian IDP policy is the result of a combination of factors at both the local and international levels. At the domestic level, pressure from national and multinational corporations on local authorities to exclude this type of migration from the agenda seems to be crucial. Likewise, budgetary concerns are relevant as the expansion of health care programs for development-induced displaced populations requires a significant increase in the allocated resources. At the international level, on the other hand, it is possible to identify two major elements. The first is the lack of a real commitment of the international regime of internal displacement with respect to this kind of exodus. Since those who suffer from such displacement are unlikely to become transnational forced migrants who endanger international stability, they are not prioritized. The UN has not made any real effort to persuade States of the need to include this population in their IDP policies. The second is international law's focus on international investment, based on a perceived weakness of the investor, which allows it to avoid regulating issues such as forced displacement.

All of these factors explain, but do not justify, the exclusion of development induced displacement from Colombian public policy. Extensive palm oil cultivation has produced an unknown number of IDPs that have, to date, not received protection or assistance. With respect to large-scale mining it seems very likely that a similar effect can be observed in the future. Now is the time to recognize the dark effects of these kinds of projects and start developing laws and effective policies in order to avoid them. Displacement must not be the price of development. 